\title{
ATTEMPTING TO DEFINE A PENTECOSTAL HERMENEUTICS
}

\author{
Marius Nel \\ Research Unit of the Faculty of Theology \\ North-West University
}

\begin{abstract}
What is distinctive about Pentecostals' reading of the Bible? In what way do Pentecostal people read the Bible so that they reach different conclusions than believers of other denominations? Is it possible to speak of a Pentecostal hermeneutics? In what way does it differ from the hermeneutics found in other theological traditions, such as the Catholic, Eastern and Reformed traditions? And how does their hermeneutics inform Pentecostals' practice? These questions are discussed and some preliminary conclusions reached. Pentecostals' religious consciousness expects an experience or encounter between God and human beings through his Spirit. This is supposed to happen in the worship service and also in the practice of Bible reading, whether individually or collectively. The presupposition is that the Word is revealed in the Bible only when people experience God, and the existential precondition leads to a Pentecostal emphasis of narratives describing such encounters in the Bible.
\end{abstract}

Key Words: Hermeneutics; Pentecostals; Encounter with God; Pentecostal Bible Reading; Narratives

\section{Introduction}

Underlying the distinctive existence of the different theological traditions is a specific way of reading and interpreting the Bible, serving as the justification for traditions existing separately from the rest of the Christian church. And these different traditions have also been produced by their specific ways of reading and interpreting the Bible. The interpretation of biblical texts leads to "sense-making with existential consequences" (Lategan, 2009:13), resulting in different theologies informing the different denominations. To demonstrate the differences in theologies, the Roman Catholic and Protestant hermeneutics can be compared.

Maas (1910:4), Pelikan (1971:108-120) and Olson (1999:131-135) describe the typical Catholic viewpoint of hermeneutics in terms of two main perspectives. In the first place, the church emphasises the inerrancy of Scripture, indicating that its hermeneutic truth is also objectively true, and that its genuine sense is adequately presented by its literal expression found in the original text and interpreted in the light of the special purpose of the Holy Ghost and of its intended circle of readers. This does not imply that the Bible always presents the whole truth under all its aspects, nor does it demand that all the sayings quoted by the Bible as historical facts are necessarily objectively true. Words quoted in Scripture as spoken by infallibly truthful speakers, e.g. by God Himself or the prophets and apostles, are not merely historically, but also objectively true; but words quoted in Scripture as proceeding from speakers open to error are not necessarily objectively true, though they are historically true. There can thus be no contradictions in the Bible nor real opposition 
between Biblical statements and the truths of philosophy, science or history because God is the author of Scripture, according to official Catholic theology (Olson, 1999:133). A second perspective (Maas, 1910:7) is found in the Council of Trent's (Sess. IV, De edit. et usu ss. II.) prohibition that, in "matters of faith and morals belonging to the building-up of Christian doctrine", the Bible be explained against the sense held by the Church, or against the unanimous consent of the Fathers. The interpretation of Scripture is unthinkable without the supervision and control of ecclesial authority and the dogmatic tradition of the church (Lategan, 2009:27).

Bahnsen (1993:1), a Reformed theologian, defines as the most important aspect of Reformed hermeneutics that the only unchallengeable authority for doctrine or life, either for the individual believer or the corporate church, is the Holy Spirit speaking in Scripture (cp. Kaiser \& Silva, 1994:25), implying that human speculation, imagination, tradition (even that of the church), or reasoning (even that labelled 'science') cannot have the aptitude or right to repudiate, replace, correct or supplement what God has revealed about himself, his works, or his will (Horton, 2011:116). Luther emphasised that it is Christ who reaches out to readers through the word, calling them to respond in faith, or to reject the call (Luther, 2004:21). Bahnsen (1993:3) adds that the process of transmitting God's word through the ages has not diminished the infallibility and authority of the original message. God continually reveals Himself as Creator, Sustainer, Governor and Judge to all mankind through the external world's order and splendour, as well as through man's internal consciousness as a rational and moral being (Erickson, 1983:197). His general or universal revelation, however, does not communicate his saving grace or plan and for this reason God has also specially revealed himself, his works, and his will in a variety of ways: By addressing individuals, by typological events and ritual institutions, by inspired proclamation through prophets and apostles, and supremely by the personal manifestation of his own Son, Jesus Christ (Erickson, 1983:179-180; Kaiser \& Silva, 1994:168). Some of these divine revelations were verbally recorded for all subsequent ages in the canonical Scripture of the Old and New Testaments, which is also itself the very revelation of God to man as a word of both information and power (Horton, 2011:117-118). The Scripture is authoritative as God's word (Grudem, 1994:73). Scripture communicates not only all of the theological and moral truths of general revelation, but goes beyond what is available to man in general revelation by especially revealing God's gracious plan of salvation and its accomplishment in history, focusing upon the work of Jesus as the Christ (Grudem, 1994:47; Kaiser \& Silva, 1994:308-309). All of God's post-fall covenantal administrations complemented (not contradicted) each other, being progressively revealed facets of the same underlying single promise of God which came to fulfilment in the person and saving work of Jesus Christ (Grudem, 1994:515; Kaiser \& Silva, 1994:309). Although unbelievers can understand the literary sense of the Scriptural text, the saving discernment, acceptance, and application of God's word requires the Holy Spirit's work of enlightenment, regeneration, bestowal of faith, nurture and sanctification (Kaiser \& Silva, 1994:88).

In the same way it is possible to speak of a Pentecostal hermeneutics or way of interpreting Scriptures. Hermeneutics is the unavoidable activity of interpretation, an intellectual quest to discover meaning, driven by a governing question: "What does the process of interpretation involve and can it even uncover indubitable meaning?" (Kennedy, 2006:164). The Greek hermeneuein was deployed by the Greeks to refer to three basic meanings: to express aloud in words or to vocalise, to explain, and to translate. Palmer (1969:14) argues that in all three cases, something foreign, strange and separated in time, 
space or experience is made familiar and comprehensible. It is interpreted and explained in order that the unfamiliar becomes familiar (Kaiser \& Silva, 1994:37).

\section{Hermeneutical Problem}

A wide variety of theoretical approaches characterise the modern hermeneutical debate (cp. Kaiser \& Silva, 1994:275-293), summarised by Thiselton (1992) as a hermeneutics of understanding; the hermeneutics of self-involvement; the hermeneutics of metacriticism and the foundations of knowledge; the hermeneutics of suspicion and retrieval; the hermeneutics of socio-critical theory; the hermeneutics of liberation theologies and feminist theologies; the hermeneutics of reading in the context of literary theory and the hermeneutics of reading in reader-response theories of literary meaning (cp. Kaiser \& Silva, 1994:34). In discussing a Pentecostal hermeneutics it should probably be classified in terms of Thiselton's categories in terms of a hermeneutics of metacriticism, where the foundations of knowledge, the basis of understanding the biblical text, and modern readers' possible relation to the text's message are addressed (Gräbe, 1997:14). ${ }^{1}$

A Pentecostal hermeneutics emphasises three elements: the interrelationship between the Holy Spirit as the One animating Scriptures and empowering the believing community (cp. Archer, 2009) with the purpose that members be equipped for ministry and witness in culturally appropriate ways (Rance, 2009:8). In the rest of the article these three elements Spirit, Scriptures and believing community - will be discussed in order to analyse the way Pentecostals interpret the Bible.

Before it can be discussed, the hermeneutical challenge should be described. While the Aufklärung demanded understanding to be objective and that truth could be found by rigorous methodical exercises, ${ }^{2}$ modern consensus is that all understanding is necessarily based on preconceptions or presuppositions determined by prior understanding engendered by being engaged with the matter involved (Gadamer, 1965:278). Readers' prior experiences and presuppositions are all part of the horizon within which they will interpret what is read with the last influencing the present horizon (Lategan, 2009:81 calls it the reader's 'personal backpack' containing past experiences, preconceived ideas, understanding of how the world works, personal prejudices, fears and expectations). It is necessary to know of the role played by pre-understanding although it is not necessary (or possible) to rid oneself of one's past or prejudices before one can partake in the act of understanding. What is necessary is rather to take them into account and place them in balance, leading to the conscious act of the fusing of horizons (Gadamer, 1965:289). To understand is according to Gadamer to confront the text with the conscious awareness of one's necessary pre-understandings or one's own 'horizon of expectation' (Thiselton, 1992:61) in order to validate or correct one's pre-understandings through the text (cp. Gräbe, 1997:17). "The ongoing cyclic process of pre-understanding - challenge - rejection or acceptance - adjustment - new self-understanding - new pre-understanding is what is understood as the "hermeneutical circle" (Lategan, 2009:81). A precondition to understanding is the consciousness of one's participation in the effective histories of the text where the different variations of historical criticism (text criticism, source criticism, form

\footnotetext{
McLean's (1994:35) argument that there is no Pentecostal hermeneutic because a Pentecostal hermeneutic is simply a "Full Gospel" biblical theology that restores the experience of Pentecost to its rightful place in Christian theology is idealistic and does not reckon with historical realities.

2 This premise allowed Evangelicals to describe Scripture as a source of objective truth and doctrinal formulation (Fogarty, 2015:2).
} 
criticism, tradition criticism and later variations such as redaction criticism) can help to explain the origins of phenomena and plotting their development (Jeanrond, 1982:4; Lategan, 2009:83). ${ }^{3}$ Bultmann already emphasised that understanding implies a living relationship between the interpreter and the text (Gadamer, 1979:295; Lategan, 2009:35), based on 'fore-understanding' because it is already presupposed and not attained through the process of understanding. When reading the Bible the Christian believer utilises necessarily a Christian existential fore-understanding (Gadamer, 1979:296) because the New Testament originated within and was specifically intended for the Christian community (Kasper, 1989:523). The Bible cannot be understood adequately only in terms of an individual's self-understanding based on his/her participation in the world but also from faith's self-understanding, determined by the fact that faith is a gracious act of God that happens to the one who has faith (Gadamer, 1976:54). Faith is a pneumatological reality (Schütz, 1985:3-4), and from Pentecostal perspective the Bible is interpreted as the product of an experience with the Spirit which the Bible describes in phenomenological language (Ervin, 1985:33), and leading to the expectation by modern-day believers that the Spirit would apply biblical truth and promises to their every-day experiences and circumstances (cp. discussion, 3.2). "The experience of the presence and involvement of the Spirit in the believer's life enables one to come to terms with the apostolic witness in a truly existential manner" (Gräbe, 1997:19), leading to a continuity with the original faith community for whom the epistle or gospel was intended, as well as the modern-day community. The results of a Pentecostal encounter with the Bible are a deepening respect for the witness of the Scriptures and especially the apostolic witnesses concerning Jesus contained in it (Gee, 1932:8); a denial that all passages should be read and interpreted literally as though the truths contained in the passage is transferred in a mechanistic or automatic way $;^{5}$ and Scriptures is read and interpreted within the pneumatic continuity of the faith community through all ages (Gräbe, 1997:19). The community is defined in terms of being Spiritdriven, Spirit-led and Spirit-empowered to accomplish God's purposes for and through the community, a community that is to be Spirit-governed, Spirit-supported and Spiritpropagated (Rance, 2009:9, responding with a Pentecostal perspective to Anderson, Venn, Nevius, Allen, and Luce who describe the characteristics of the New Testament church in terms of the Three-Self formula as contextually self-propagating, self-governing, and selfsupporting; cp. Reese, 2007:25-27).

3 Pentecostal scholars maintain a commitment to the reliability of biblical narrative while at the same time tending to align themselves with Evangelicals in their move toward adopting the methods of higher criticism, leading Pentecostal scholars in Cargal's (1993:169) opinion on the one hand to emphasize the historical context of the biblical texts and to reduce their meaning to the intent of the authors while on the other hand they emphasize the immediacy of the text in a canonical sense and multiple meanings. In this way they attempt to navigate the waters of complicated modern reading practices.

4 E.g., Lake (1994:41) writes that a successful Christian life rests on three essentials: a knowledge of the teaching of Christ whose words in the New Testament are the final authority, a willingness to do all the will of God as declared by Jesus, and a recognition of the Spirit as revealer, guide, interpreter, teacher and empowerer to understand Scriptures.

5 Early Pentecostals read many passages in a typological way, "feeling led by the Spirit" that the events in the Bible were prefigurations of what would happen in their day, which constituted the "last days" (Olson, 1999:566-567). A person who has experienced healing or who speaks in tongues reads passages relevant to these experiences radically different from a person who has not experienced either. Ervin (1985:33) explains that when one encounters the Spirit in the same apostolic experience, with the same charismatic phenomenology accompanying it, one can come to terms with the apostolic witness in a truly existential manner. You stand in continuity with the faith community that birthed the Scriptures. 
If understanding is defined as the fusion of horizons conditioned by effective historical criticism, the important question remains: how does one validate one's experience with the text? Ricoeur was concerned about text comprehension and showed that the relationship between interpreter and text should be approached methodically in a critically accountable way (Jeanrond, 1986:27). The interpretive process is dialectical, progressing from an initial naive understanding to an explanation of the text, and a deeper understanding of the text and a methodological validation of the results of the first or naive understanding (Jeanrond, 1982:5; 1986:42).

True understanding always includes the act of application (Gadamer, 1979:270). The text that is understood historically is always forced to abandon its claim that it is uttering something true, argues Gadamer, and the acknowledgment of the otherness of the other involves the fundamental suspension of its claim to truth, leading to the dilemma of theology when Scripture is applied in an edifying way in Christian preaching (Kaiser \& Silva, 1994:329). Understanding always involves the application of the text to be understood to the present situation of the interpreter (Gadamer, 1979:274; Kaiser \& Silva, 1994:328).

The relation between interpreter and text consists in 'understanding;' the methodological activity taking place between interpreter and text leads to 'explanation;' a last element consists in 'assessment', consisting of the reader's personal responsibility towards the meaning of the text that opens up before them (Jeanrond, 1986:70, 125). Assessment of biblical texts consists of discovering the claim(s) made by the text and making a personal response to it.

By way of concluding, faith does not render scientific methodologically controlled interpretation of biblical texts impossible but forms the framework that makes the enterprise meaningful (Stuhlmacher, 1979:204). However, the ceaseless movement of biblical interpretation begins and ends in the risk of a response, which is not exhausted by commentary (Ricoeur, 1975:31). Faith forms the necessary and unique from which basis believers orientate them in all their choices. Hermeneutics reminds that biblical faith cannot be separated from the movement of interpretation, which elevates it into language (Kaiser \& Silva, 1994:56; Gräbe, 1997:23).

Faith is interpreted from a Pentecostal perspective as a transforming and empowering encounter with the divine, as described in Acts, leading to a Christian community eager to bear witness to the power and love of God that they experienced (Schnackenburg, 1974:8182) and a consciousness of the real presence and power of the Spirit. ${ }^{6}$

Paul bases faith pneumatologically when he relates the proclamation of the gospel to the power of the Spirit, giving rise to faith resting on the powerful working of the Spirit (Rom. 15:18-19; Gal. 5:22; 1 Thess. 1:5-6) (Gräbe, 1990:355). The Pentecostal movement believes that the Spirit has manifested himself again with glossolalia, prophecy, miracles of

\footnotetext{
"To be Pentecostal is to have experienced the power of God in Jesus" (Clark \& Lederle, 1989:43).

Pentecostals emphasise that the working of the Spirit would be accompanied by power, including signs, wonders and the miraculous. They see it as the "standard operating procedure of a New Testament/indigenous church" (Rance, 2009:15). In this way the apostolic mandate is fulfilled in apostolic power when the events that the New Testament relate also happens in the present-day church. It is the Spirit who enables believers according to Pentecostals to perform effectively the tasks assigned to each believer in the Christian ministry. Performance of these tasks is urgent since they believe that the second coming of Christ is imminent. The Holy Spirit gives supernatural ability to Christians to witness, including power to preach the Bible, power to cast out demons, heal the sick, and offer protection from evil forces (Onyinah, 2012:1). Lake (1994:29) calls this the secret of the ministry of Jesus Christ and of Christianity, that the Spirit of God imparts his power to Christians and allows them to live in union with the living God through his Spirit indwelling them.
} 
healing and other signs happening in contemporary times. ${ }^{7}$ They now read the Bible in order to understand themselves (Ricoeur, 1975:30), a mode of subjectivity which responds and corresponds to the power of the New Testament to display its own world radiated by the living Lord and present among his people, the community of faith, through the Holy Spirit. And they also expect these same signs and wonders to occur in their ministry; they prioritise spectacular displays of celestial power, such as healing and deliverance from sinful habits and Satanic bondage, to authenticate the preaching of the Word and leading to faith in the Word (Anderson, 2003:5). ${ }^{8}$

\section{The Centrality of the Holy Spirit}

At the heart of classical Pentecostalism stands the Bible as the inspired Word of God, affirming that the (whole) Bible is a reliable revelation of God, and that it states the exact truths the Holy Spirit intends to convey (Arrington, 1994:11). The starting point and foundation for Pentecostal faith and praxis is the biblical text, making the real issue in Pentecostalism hermeneutics, which is defined in Pentecostalism in terms of the role of the Spirit in realising the distinctive nature and function of Scripture in the faith community (Arrington, 1994:107). ${ }^{9}$ The three main elements of a Pentecostal hermeneutics can thus be described as: The interrelationship between the Holy Spirit as the One animating Scriptures and empowering the believing community with the purpose that members be equipped for ministry and witness in culturally appropriate ways. These three elements are now discussed in order to demonstrate how Pentecostals interpret what they read in the Bible.

\section{Holy Spirit as the One who Realises the Christ-event in the Present}

The accusation has been levelled at Pentecostals that they emphasise the work of the Spirit at the cost of the Christocentric gospel (Möller, 1997:140). ${ }^{10}$ However, Pentecostals teach that the experience of an encounter with Christ is the result of the Spirit's (the Spirit of Christ) revelation that never leaves a person neutral (Ma, 2005:8). ${ }^{11}$ The center of the Christian message is Jesus Christ, Pentecostals will confess, but what is critical for them is the personal awareness and experiencing of the indwelling of the Spirit who sets Jesus present in the daily life of the believer (Williams, 2015:1). The Spirit determines the process. "It is the Holy Spirit that calls, it is the Holy Spirit that inspires, it is the Holy Spirit that reveals and the Holy Spirit that administers" (Wilson, 1998:127). ${ }^{12}$ And this is

For centuries these phenomena were seen as accompanying the missionary origins of the early Church and primitive phenomena suitable for "beginners in the faith" (Schnackenburg, 1974:82-82).

8 Anderson (2003:6) emphasizes that healing is no longer a prominent feature of Western Pentecostalism but in the Majority World the problems of disease and evil affect the whole community and are not relegated to a private domain for individual pastoral care, leading to a constant need for ministering healing to people.

9 "The essence of Pentecostalism is its persistent emphasis upon the supernatural within the community" (Archer, 1996:64).

10 FP Möller was the leader (or president) of the Apostolic Faith Mission of South Africa from 1966 to 1988 and wrote extensively about Pentecostal theology (Jooste, s.a.:58-75, 101-123). His books on Pentecostal Systematic Theology play an important role in South African Pentecostalism.

11 Clark (2011:11) emphasises that Pentecostalism in the South resembles the classical Pentecostalism of the first and second generations after Azusa Street in its forms, dynamic and articulation, with the message of Jesus seemingly coming to the fore more readily than does the message of the Spirit. He remarks provocatively that Spirit-centred thinking is more likely to lead to syncretism because of the spirit-centred nature of the religious context in much of the South.

12 Pinnock (1993:3) distinguishes between an original inspiration and contemporary illumination by the Spirit, acknowledging the Spirit's involvement in the process of forming Scripture as well as guiding the 
followed in the Pentecostal perspective by the "Baptism of the Holy Spirit for Service," as Moody expressed it in his Doctrinal Discourses of 1877 (Dayton, 1987:102). ${ }^{13}$ The doctrine is upheld that the Holy Spirit dwells in some sense, and to some extent, in every believer, but there is another gift that Pentecostals expect and wait for - Moody describes it as the gift of the Spirit for service - and which is entirely distinct and separate from conversion and acceptance of the forgiveness of sins. Christians need this gift in order to be empowered for service (Daniels, 1877:396-403, quoting Moody; Harper, 2008:105; McQueen, 2009:3 emphasises that this takes place in the context of Pentecostal emphasis that it is every believer's responsibility to be a witness of truth, grounded in a distinct belief in the priesthood and prophethood of all believers). Möller (1975:43-44) describes this experience as a gift of grace based on the promise of Acts 1:5, 8, that God would reveal Himself in a personal, immediate, intimate and lasting way to believers by bringing humans under the control and fullness of his Spirit, leading to their sensitised consciousness of the risen and glorified Christ in their lives and resulting in being more effective witnesses for Christ and worshipping Him in a fuller dimension. "The Holy Spirit is personally and powerfully present to orchestrate the continuing redemptive ministry of Jesus Christ to the uttermost parts of the world" (Klaus, 2006:4). While Protestants emphasise orthodoxy (correctness in doctrine and confession as derived from Scripture), Pentecostals stress orthopraxy. They do not deny the importance of doctrine being founded on the Bible ${ }^{15}$ but they seek validation of doctrinal truth in dynamic activity in the Spirit. In their preaching they do not primarily aim at communicating doctrinal truths but to minister to the spiritual, physical, psychological and social needs of the people assembled to meet the Word, Jesus Christ (Clark \& Lederle, 1989:64-65). ${ }^{16}$

contemporary community as it walks with God in the light of its Scriptures toward the fulfillment of its mission. "The Lord is present in scripture and the Spirit is present in the reader who has faith (Cullmann, 1956:99).

13 For most Pentecostals, the initial sign of Spirit Baptism is speaking in tongues.

14 The presupposition is that Pentecostals would be more effective than Christians from other denominations to reach the lost world with the gospel. Statistics for the 25 largest faith groups in the United States show that the only two orthodox Christian groups growing on the list were the Assemblies of God and Church of God, both classical Pentecostal denominations (Stetzer, 11 November 2014). In an article in Christianity Today, "Why do these Pentecostals keep growing", Stetzer discusses possible reasons why Pentecostal churches are experiencing a higher growth rate than most other groups. Pentecostals themselves argue they are growing because the Spirit is moving in a powerful way. Other sociological reasons can explain the phenomenon: Speaking in tongues follows the Holy Spirit's baptism, with Pentecostal believers and churches emphasising spiritual practice and engagement, leading to a more robust faith and the need to share it with others. Not only does the distinctive of Spirit baptism encourage participation and growth in the local body, but it also provides an imperative for growth outside of the local body. Pentecostals feel that others should have the same opportunity to partake of the movement of the Spirit of God. When you experience your expression of faith as worth sharing (be it Pentecostal, Calvinist, or Anabaptist), you are more likely to share it with others and start new churches (http://www.christianitytoday.com/edstetzer/2014/november/why-are-pentecostalsgrowing.html?paging=off. Accessed 2015-04-02). Clark (2011:7) notes the difficulty in evangelising majority Marxist, Muslim, Hindu and Buddhist communities with a rational Christian voice, while Pentecostals demonstrate that any person of any religion can be touched by the power of God through the distinctive Pentecostal ministry of the pneumatica. "Even the most aggressive established religions and spiritualities find it difficult to negate this subtle and informal subversion."

15 It can, however, not be denied that Pentecostal groups are more prone to heretical teaching than other established groups, as the extent of the influence of the prosperity gospel demonstrates (Horn, 1989:71). ministry to people in need, changing the worship service into an experiential event for attendees. 
The emphasis on experience of an encounter with Christ can be linked to postmodern thought. ${ }^{17}$ Pentecostalism stands over against Modernism's philosophical presupposition, shared by Fundamentalists, that only what can be proven to be historically and objectively true is meaningful (Cargal, 1993:168). ${ }^{18}$ Pentecostal hermeneutics share with postmodern thought other presuppositions as well, such as multiplicity of meaning and the dialogical role of experience (Cargal, 1993:187), ${ }^{19}$ even though McQueen (2009:4) is correct in warning that the Pentecostals' worldview differs in other important respects from the postmodern worldview. Central to the Pentecostal worldview is the confession that God speaks and acts today as he did as recorded in the Bible, leading to a high valuation of experience and non-rational forms of knowing and a resultant unfortunate skepticism toward learning and higher education, as something almost opposed to the (S)spirit (Turnage, 2003:9). Stronstad's (1992:25) analysis of a Pentecostal hermeneutic consists of three elements, that it is experiential, at both levels of presupposition and verification; rational, by incorporating historical-grammatical principles of exegesis; and pneumatic, as it recognises the Spirit as illuminator and inspirer of Scripture. However, the analysis is positivistic and limited to a segment of a diverse Pentecostal movement, where a majority conservative part devalues the second element consisting of rational forms of knowing. ${ }^{20}$

Kraus (1979:58-59) distinguishes between Pentecostalism and fundamentalism by ascribing to Pentecostalism a charismatic element over against fundamentalism's didactic emphasis; Pentecostalism's Wesleyan/Arminian theological orientation against fundamentalism's Calvinistic; with gifts of the Spirit providing assurance for Pentecostals against fundamentalists gaining assurance from an inerrant Scripture, Pentecostalism's experiencecentred against fundamentalism's theology-centered orientation, and with Pentecostalism recognising non-rational elements against fundamentalism emphasising rational elements. Pentecostals emphasise re-experiencing the biblical text through preaching an immediate meaning for Scripture, sometimes with little or no significance placed on the original

17 Cf. Letson's (2007:113-116) proposal that Pentecostalism represents a new paradigm shift with its new way of seeing Christian experience, in terms of Hans Kung's identification of paradigm shifts within Christianity and in correlation with Thomas S Kuhn's discussion of the structure of scientific revolution.

18 Poloma (1989:xix) remarks that one sociological factor for the phenomenal growth of the Assemblies of God in the USA has been its ability to offer "an anthropological protest against modernity" by "providing a medium for encountering the supernatural ... (and) fus(ing) the natural and supernatural, the emotional and rational, the charismatic and institutional in a decidedly postmodern way."

19 Some Pentecostal scholars use postmodern literary theory in their endeavour to construct a hermeneutic more closely aligned with Pentecostal practice (cp. discussion in Arrington, 1994:100-109; Harrington \& Patton, 1994:109-114; Menzies, 1994:114-120; Sheppard, 1994:121-141). Other Pentecostal scholars, such as Gordon Fee, William and Robert Menzies, have bought into the conservative evangelic hermeneutic, limiting the meaning of Scripture to the intent of the author, and thereby hindering the freedom of the Spirit to speak through the Word (Cargal, 1993:164). Pentecostals have been concerned all the time that seminary trained preachers are so exegetically "correct" (using along others historical-critical methods) that they do not reach their audience and undermine the dynamic of the early Pentecostal movement (Fogarty, 2015:5). PL le Roux (1936:5), an important South African Pentecostal leader during the second generation of the movement, verbalised the viewpoint of many Pentecostals: "Ons dank die Here vir die beweging wat vierkantig op Gods Woord staan, en alles aanneem wat die Here gesê het. Ja, die Pinkstergelowiges, gevul met die Heilige Gees, glo alles wat geskryf staan... En omdat hulle die woord aanneem en daarop vertrou, word die waarheid daarvan in hulle ondervinding bevestig. Hulle kan sê: 'Ek weet dit is waar; nie net omdat dit in die Bybel geskrywe is nie maar my eie ondervinding bevestig dit"" ("We thank God for the movement built squarely on God's Word, and accept everything that the Lord has said. Yes, Pentecostal believers, filled with the Holy Spirit, believe everything that is written ... And because they are adopting it and relying on it, its truth is confirmed in their experience. They may say, 'I know it's true; not only because it is written in the Bible, but it is confirmed by my own experience"'). 
context, and accompanied by the giving of testimonies that God is still working miracles in the present as found in biblical narratives (Fogarty, 2015:5).

The experience of the baptism with the Spirit is designated in the Bible with other terms as well, such as being filled with the Spirit, endued with power from on high, the Spirit falling on people, the gift of the Spirit, and receiving the Spirit. Pentecostals emphasise that it is clear from the New Testament that it refers to a definite and distinctive experience of which one may know whether one has received it or not, and that it is a work separate and distinct from the Spirit's regenerating work (De Beer, 2014:360). The baptism with the Spirit is always connected with testimony and service (Torrey, 1895:9-14). "It is the personal and direct awareness and experiencing of the indwelling of the Holy Spirit by which the risen and glorified Christ is revealed and the believer is empowered to witness and worship with the abundance of life as described in Acts and the Epistles" (Menzies, 1970:2). Klaus (2006:8) speaks of believers' participating in Christ's continuing redemptive ministry, empowered by the Spirit before Christ's return.

The consequences of the Spirit baptism are a quickening of the believer's 'natural powers;' a vast accumulation of moral and spiritual power; soul-transforming apprehensions of Truth; absolute assurance of hope; more intimate fellowship with the Father through his Son, Jesus; a deep and permanent spiritual blessedness; and a unity of Spirit among believers (in the words of Mahan, 1870:52).

The risen Christ is a reality that believers experience on a continual basis through the working of the Spirit. "Der Heilige Geist ist im neutestamentlichen Denken die Kategorie der Gegenwart..." (Wendland, 1952:458). The Spirit empowers the believing community by introducing them to Christ and by enriching them with his gifts and fruit. The Spirit bridges the gap between encounters that early disciples had with Jesus and present encounters with Him (Veenhof, 1987:115), leading them in all truth (John 16:13). The Spirit is the power through which the exalted Lord is present in the history of the cosmos as principle of a new history and a new world (Gräbe, 1997:14). "The baptism into the Holy Spirit is not an encounter with the Spirit but with Christ, the baptiser. This means total surrender and absolute commitment to Jesus. Without this He cannot baptise you in the Spirit" (Du Plessis, 1963:71).

Pentecostals interpret Ezekiel 37 as the work of the Spirit in the age of the new covenant to revive the dry bones, and Isaiah 44 as bringing seemingly dead people to new life and vitality (Schafroth, 2009:62-63). As the rain brings the promise of new life and vitality the outpouring of the Spirit promised in Joel 2 and 3 is interpreted as leading to a new dispensation, related to the Spirit (Lochman, 1982:149). Lochman (1982:150) describes the 'new' element in terms of 'Vergegenwärtigung' (making present of) and 'Teilhabe' (gaining part of); the Spirit is the power through which God is made present in the Christ event, allowing God to be involved and partake directly in the life of the presentday church. Christians live in the 'relevant presence of God' (Gräbe, 1997:16), changing their perspective on reality dramatically.

Not only does the Spirit in the daily lives of believers introduce God but the Spirit also allows believers to partake in the Divine. People are not only the object of God's interest but they are also addressed in their subjectiveness, as subjects who have to answer. The Crucified and Resurrected Lord is present in the midst of his people; to understand in what way, it is necessary to know what the New Testament teaches about the Spirit, explaining Pentecostal interest in the subject (De Beer, 2014:380). For Pentecostal people the apostolic witness is crucial, as can be seen in their preference for the term to be incorporated in the 
early Pentecostal movement. ${ }^{21}$ The apostles were the direct witnesses of Jesus' life and ministry and their message is seen as of primary importance. The New Testament as the result of their preaching sees an essential identity and continuity between Jesus of Galilee and the Lord who promises to be with them always - to the end of time (Matt. 28:20).

\section{Holy Spirit as the One who quickens and animates Scriptures}

Archer (2009:160) comments about Pentecostals' life with the Bible:

Pentecostals love their Bible. Biblical themes, stories and significant biblical numbers (3,

7, 12, 40) permeated Pentecostal literature. More importantly, these things saturate Pentecostal oral testimonies. In their narrated testimonies, one can clearly hear echoes of biblical stories, themes and phrases. Pentecostals assimilated scriptural stories, verses and concepts into their interpretation of reality.

The Bible speaks about God and claims to be his Word, a claim that results in Pentecostals' acknowledgement of the homiletical value of the Bible and the necessity of the Spirit's guidance in interpreting it. ${ }^{22}$ However, it is not doctrine or tradition that makes Pentecostalism what it is; it is the presence of God in and among his people "in a manner which is readily evident to participator and bystander alike" (Clark \& Lederle, 1989:65). Pentecostal experience of the Spirit is in Pentecostal hermeneutics the legitimate presupposition of biblical interpretation (Stronstad, 1992:18). For this reason, the goal of studying Scripture is "knowledge of (not simply about) God" (Autry, 1993:42). Understanding Scriptures serves the larger aim of knowing God. Pentecostals emphasise that the authority of the Spirit comes before the authority of Scripture. "The Spirit was over the church. The Spirit was prior to Scripture. So, the order of authority was Spirit, Scripture, church. Without the Spirit there would have been no Word, incarnate or written; without the Word, no church" (Ellington, 1996:24).

The same God who spoke and acted in salvation-history events and in the inspiration of Scriptures speaks and acts today, and Pentecostals read the Bible in order to find the hermeneutical implications of God's present activity in the faith community (McQueen, 2009:3-4). The Bible does not per se present itself as the Word of God but what we read in the Bible is mentioning of or references to the Word of God (Möller, 1991:91). Although God inspires the Bible everything in the Bible is not from divine origins or a report of God's words and acts. Biblical writers utilised information available to their contemporaries and at times reported what they heard. The words of sinful and uninspired people are also written down. That the Bible is inspired implies that what is written down in the Bible is what God wanted to present to people and what is necessary for sinful man to know about God and how to live in the correct relationship with Him (Nelson \& Wawire, 2004:14). The Bible is called the Word of God when it contains something that Jesus revealed about God (John 14:24; 17:14, 17), as a reference to the message of the gospel (Rev. 1:2,9), or what God revealed to the prophets and other individuals (Isa. 2:3; Dan. 9:2; Hos. 1:1; 1 Thess. 4:15) (Möller, 1991:91).

21 E.g., the Azusa Street Mission where the Pentecostal movement originated was called "Apostolic Faith Mission" (Burger \& Nel, 2008:18) and the earliest magazine published by the Mission was called "The Apostolic Faith" (McClung, 1986:22).

22 In one of the earliest editions of The Apostolic Faith (June to Sept. 1907, 1(9):1), William J Seymour who led the Azusa Street Mission writes: "We're measuring everything by the Word, every experience must measure up with the Bible. Some say this is going too far, but if we have lived too close to the Word, we will settle that with the Lord when we meet Him in the air." 
The Word is God but the Bible is not God. ${ }^{23}$ The Bible is the written witness about the Word of God, a road sign indicating the way to God and containing everything needed by humans about God and his will (Möller, 1991:93). As a result, Scriptures are viewed as the primal point of reference for encounter with God because " $(\mathrm{t}) \mathrm{o}$ encounter the Scriptures is to encounter God" (Johns, 1993:14). Reading Scriptures should lead to affective transformation to be effective, although it does not exclude intellectual understanding as necessary in Pentecostal understanding of truth based on Scriptures.

McQueen (2009:5) argues that a distinctive Pentecostal experiential pre-understanding determines how Pentecostals read the Bible, and experience plays a dialogical role in opening up the biblical text. Although he (2009:6) adds that the communal nature of a Pentecostal hermeneutic demands that conclusions reached be viewed as one member's voice among the other members of the Christian community, he uses his Pentecostal experience to interpret Joel in an invalid way (McQueen, 2009:106-107). He bases his reading of the Bible on Moore's (1995:23) suggestion that an implosion of "utter confession and utter criticism" occurs at the core of the Pentecostal experience. In those moments of intense encounter and communion of the believer with the Spirit, known in and expected by the Pentecostal community, confession is evoked by the claim of the Spirit. The believer is so claimed by the Spirit as "to be disclaimed, to be seized, taken captive and dispossessed of everything previously claimed," that these moments become critical. And even though it occurs outside the dialectic of text and reader, yet it opens up a different reading of reality and a different reading of the text (Moore, 1995:23). To be a Pentecostal interpreter of Scriptures, one's confession about the text must agree with the previously evoked confession about the Spirit. The claim of the Spirit will be in agreement with the claim of the text, and one comes to know the claim of the text in the light of the claim of the Spirit (McQueen, 2009:106). This is where the danger of subjectivism looms, as McQueen (2009:107) illustrates when he describes his experience of "a glorious encounter with the Spirit who filled me with rejoicing... Groans were replaced with glossolalia, and I was filled with a new sense of emotional and intellectual integration." In this way his conclusions in reading Joel was illuminated by Pentecostal experience. His experience allows him to look "with new eyes intuitively focused" on the biblical book and three 'confessions' arose out of the encounter: That the book of Joel enjoys literary and theological unity; that the theme of judgment in the book should not be subsumed under the theme of salvation, as happens in many commentaries, but should form a separate and third theme; and that the transitions between the three movements of the book of Joel are found in the interaction of human cry and divine response (McQueen, 2009:107-108). However, these conclusions are based on a rational reading of the book and to claim a pneumatological precedent for attaching authority to one's understanding of the biblical book is rather subjectivist and far-fetched. ${ }^{24}$

23 Reformed theology makes a distinction between special (revelatio specialis) and general revelation (revelatio generalis), with the Bible as special and nature as general revelation, a distinction not upheld by most Pentecostals because it implies that there is more than one kind or nature of revelation. It is true that there are several things that witness to God's self-revelation and provide information about this event, as found in the Bible, creation, human beings, the fellowship of believers, etc. This does not imply that there is more than one self-revelation but that there are several media that serve as witnesses and means of revelation (Möller, 1991:100).

24 "Pentecostals do not found their understanding of the authority of Scripture on a bedrock of doctrine, but that, in fact, their doctrine is itself resting on something more fundamental, dynamic and resilient; their experience of encountering a living God, directly and personally" (Ellington, 1996:17). 
Pentecostals emphasise that Biblical truths should be seen not to be actualised in the lives of individuals by humans repeating the truths and promises contained in Scriptures or even understanding it on a rational level but by the working of the Spirit in the human heart. The Bible does not contain anything that humans may use to get a grip on God and to realise his promises (De Beer, 2014:365) but true confession and faith is the result of the revelation of God's Word in and through the human being, by the working of the Spirit. Wessels (1992:382-383) describes how one of the South African Pentecostal churches developed from a spontaneous interaction between the Word of God and experience of the Spirit where the biblical 'truths' were read and believed smoothly and experienced, to that of a church with complicated organisation and structures, with its related social involvement and intellectual development, and with members becoming more critical. Spontaneous experience of faith was eventually complicated by a more critical attitude. The relation to the Bible became more formal as the church found it necessary to consult it with regard to urgent critical issues, resulting in tension between the Bible and its authority, and the experience that flowed from it. Both components subsisted but the spontaneous interaction between the two was lost (Wessels, 1992:384).

Möller (1991:97) distinguishes between fides humana and fides divina at the hand of 1 Corinthians 2:4-5's reference to Paul's proclamation that was not "meant to convince by philosophical argument, but to demonstrate the convincing power of the Spirit, so that your faith should depend not on human wisdom but on the power of God." 25 Pentecostal hemeneusis allows that a passage in Scripture may address an individual in certain circumstances while at a later stage in different circumstances the passage does not address the same person (Van der Walt \& Jordaan, 2004:508); the Spirit convinces the reader that the specific encounter with the Bible passage contains a unique revelation of God for them (Althouse, 2009:8). This, however, does not imply that the study of the Bible should not try to find out what the biblical writer intended as a message for the original listeners or readers (hermeneutics).

Pentecostals believe that the Bible contains not only the Word of God for human beings but also a specific word for them as a way of guidance. A result of reading the Bible prayerfully in the belief that the Spirit will reveal Christ (or the Word) to them is that they apply promises from the Bible as though it is given to them when they experience that the Spirit highlights a specific passage for them. In this way they read the Bible from a promise-fulfilment scheme, applying certain passages to their daily situation (Rance, 2009:17. This may lead to the situation where the Bible is read a-historically as though the text has no history or an underlying theology or ideology, allowing them to find an uncomplicated message directed to their present-day circumstances, a kind of lectio divina borrowed from mystical theology. Their purpose is to hear the Word for their situation through the Spirit, in order to experience the Word in their daily lives. The working of the Spirit (subjectively evaluated) is then supposed to guarantee that the Word becomes the truth of God for them in today's world. ${ }^{26}$ The danger is evident, that the reader hears in the Bible what they wish to hear. ${ }^{27}$

25 Biblical quotation is from The New Jerusalem Bible (1985; London: Darton, Longman \& Todd).

26 Pentecostals agree with Karl Barth who described Scriptures as becoming the Word of God to the reader or hearer through the action and participation of the Spirit (Clark, 1997:57; Fogarty, 2015:7).

27 The same may happen when Pentecostals allow for a directly inspired word from God functioning outside the narrow borders of the Bible, called prophecy, where one person feels inspired by the Spirit to speak a personal and individualised word to another or the assembly as they perceive it to be a word from God. 
How can dangerous subjectivising tendencies in a Pentecostal hermeneutic be avoided? Thomas (1994:43) suggests a holistic Pentecostal hermeneutic which incorporates both Spirit and experience and he deduces his paradigm from Acts 15, where Spirit and community play an important role in the interpretive approach regarding the issue of Gentile Christians. He observes that the interpretive process moves from the believing community's context to the biblical text. This reverses the order of exegetical processes that normally start from the text and then moves to the context. The Spirit enables the community that depends upon the Spirit to enlighten them in the interpretive process. This dependence goes far beyond evangelical claims to "illumination by the Spirit." The Spirit actually guides the community into a new understanding of God's will. The three primary components in the hermeneutic are the community, the activity of the Spirit and Scripture. These components are not static but in dialogue with each other. The community testifies to the experiences attributed to the Spirit and then engages Scripture to validate or repudiate the experience or issue. A dynamic balance is needed between individual, Spirit, Scripture, and the faith community (Ellington, 1996:28). In this way Scripture is authoritative and central to the rule and conduct of the church. Pinnock (1993:4) explains that the community needs the controlled liberty of the Spirit, where the Spirit takes what the inspired authors intended to say and discloses its significance, its meaning for the contemporary community. The original meaning is determinate and does not change, but God's Spirit in his working out of salvation history uses this witness in new ways in ever new settings, creating significance for readers and hearers. "The Spirit is active in the life of the whole church to interpret the biblical message in the languages of today. He actualises the word of God by helping us to restate the message in contemporary terminology and apply it to fresh situations. The result is that salvation history continues to take effect in us" (Pinnock, 1993:4).

In his quantitative research, Huckle (2009:84) found that prophecy influences the contemporary American Pentecostal church to a large extent, that prophecy is understood in terms of personal and communal enlightenment and encouragement and that nearly $95 \%$ of fellowships surveyed used Scriptures to judge prophecies, as doctrinal statements of these denominations require. However, most respondents did not bring prophecy into relation with explication of Scriptures, as is the case in Protestant praxis. Prophecy did help some to apply the Bible to a specific situation, or emphasise the blessings of God as expounded in Scriptures, but they realised that it should not be viewed as additions to the written Bible. Where they have been equated with Scripture, the dangers of heretical doctrine being propagated became very real. ${ }^{28}$

\section{Holy Spirit as Present among his People, the Community of Faith}

What distinguishes Pentecostal Bible reading from other traditions is not a different interpretive method but a distinct narrative which leads to a coherent and cohesive interpretive manner in which the Spirit plays the most important role and the community of

28 Liardon (1996:333-341) demonstrates the danger when he describes the end of the powerful ministry of William Branham, characterised by his attributing personal prophecies with the same authority ascribed to the Bible. 
faith and its story forms the influential hermeneutical filter as pre-understanding forming the condition for understanding. ${ }^{29}$

The use of any method is not objectively free from the social and cultural location of the person utilising it; both method and person-in-community have been historically conditioned (Archer, 2009:129). Comprehension is both discovery and creation of meaningful understanding (Lategan, 1992:153-154). McQueen (2009:109) also emphasises that methodology can never be value-free. There must be a correspondence between method and content, between formal and substantive matters. He concludes that a hermeneutic that embraces the critical claim of the Spirit simply cannot be fitted into a methodology that allows reason to be the final arbiter of truth, no matter how critical or creative the results.

Although the Pentecostal community is part of the larger Christian community, yet it exists in distinction from the rest of the Christian world due to its distinct narrative tradition. The Pentecostal community is bound together by a shared Pentecostal experience of the baptism with the Spirit, leading to a shared story based on the meta-narrative of the general Christian story about the meaning of creation and God's role in creation, as derived from the general narrative found in the Bible (cp. Fackre, 1996:8-9; Nelson \& Wawire, 2004:14). However, Pentecostals concentrate specifically on the narratives found in the New Testament relating to encounters of early Christians with the Holy Spirit leading to an emphasis on the books of the synoptic Gospels (with a predilection for Luke - Mittelstadt, 2010:2-3) and especially Acts of the Apostles (Hollenweger, 1988:336; Mittelstadt, 2004:2). Because the Pentecostal community understands itself to be a restorationist movement; it argues in many instances also that it is the best representation of Christianity in the world today because it is an authentic continuation of New Testament Christianity as well as a faithful representative of New Testament Christianity (Archer, 2009:133). However, its conservative nature also allows for operating legalistically when it succumbs to over-literal interpretations of Scriptures, leading it to become socially unhelpful, for instance, in the age of the earth debates, the role of women in the church and society, and the uncritical acceptance of the authority of governments (Clark, 2013:3). Rather, Clark argues, the Bible should be used to provide direction and boundaries to proclamation and experience, with 'text' and 'Spirit' proving balanced emphases.

Pentecostals regard their narrative tradition as synonymous with the New Testament narratives of experiences with baptism in the Spirit, and this narrative tradition provides the context for their search for meaning when they read the Bible. ${ }^{30}$ In this way an experiential narrative forms the hermeneutical framework for interpreting Scripture, as well as expe-

29 As compared to Catholicism, institution and office are largely played down by Pentecostals; their preference lies with the community and the ministry (or "charism") of each member of the community. Office arises amongst the Pentecostals as recognition of ministry. Institution, ordination or certification do not automatically confer ministry (Clark \& Lederle, 1989:64).

30 Australian Pentecostal John Penney (in Anderson, 2003:3) says that the experience of the day of Pentecost in Acts 2 becomes a "normative paradigm for every Christian to preach the gospel," and that Luke's "primary and pervasive interest is the working of the Holy Spirit in initiating, empowering and directing the church in its eschatological worldwide mission." The main causes for the growth of Pentecostal churches identified by church growth specialists can be explained by reference to the experience of Spirit baptism (Anderson, 2003:3). Friesen (2009:54-55) shows how Charles Parham, founder of the Apostolic Faith Movement in Topeka, Kansas, already argued in 1902 that speaking in tongues is a tool of evangelism. "The purpose of Spirit baptism was the spreading the gospel to the ends of the earth quickly without having to waste time learning foreign languages." This formed the basis for the movement's emphasis on foreign missions. The question whether contemporary experiences of the Spirit and the experiences of the early church of the first century CE are compatible is nowhere answered by Pentecostals. 
riencing reality. ${ }^{31}$ Their narrative tradition allows for God's involvement in restoring the Spirit and its gifts to the Christian community, and God's dramatic involvement in their reality and Biblical events are interpreted to allow for the same miracles and interventions from the Other Side to happen in their world. They desire to live as the eschatological people of God as part of the final drama of God's redemptive action, during the last of the last days before the second coming of Christ.

All reading is a transaction between the biblical text and the community, which results in the finding of meaning approximated by the reader (Hart, 1995:107). Between the biblical text and the community there is a dialectical encounter made possible by a working plot within the biblical story that is recreated in the community. Hawk (1991:19) explains that a plot functions on the surface level of a tale as the framework of the story and as the arrangement of incidents and patterns as they relate to each other in a story but the abstract notion of plot also operates within the mind of the reader who organises and makes connections between events, and relates present-day experiences to the plot in the tale (Hart, 1991:27).

The Pentecostal community reads Scripture in order to develop a praxis where biblical tales are placed into the cohesive Pentecostal narrative tradition that interprets Pentecostal existence in terms of the outpouring of the Spirit. Biblical tales challenge and reshape Pentecostal tradition and provide the language to describe their praxis. In this way the encounter between biblical text and community is dialogical as well as dialectical, and the search for and approximation of meaning takes place primarily within the community (Fish, 1980:34). Pentecostal interpretation of the Bible includes an act of obedient response to the Scripture's meaning (Archer, 2009:136), as perceived by the Pentecostal community.

Stronstad (1984:49) challenges two standard evangelical principles of hermeneutics, using textual evidence: In the first place, evangelicals' hermeneutical principle to use Paul to colour all discussions of the Holy Spirit; he argues that Luke's and Paul's pneumatological lenses were different, with Paul using primarily salvation-initiation language while Luke uses subsequent-empowerment language. He suggests that Luke should be left to speak for himself and that it would demonstrate the uniqueness of Luke. The second principle he challenges is that the didactic genre of Scripture should be the domain of doctrine while the narrative genre should be used for history's sake. Stronstad demonstrates the legitimacy of the narrative genre to carry theological intent, recognising the legitimacy of the Pentecostal nexus that shapes Pentecostal mission and mission strategy (cp. Menzies, 1991; Penney, 1997:84). ${ }^{32}$

Two important differences between Pentecostals and many Evangelicals flow from Pentecostals' emphasis on the Spirit's involvement in explicating Scripture: They emphasise an immediate and experiential meaning for Scripture that does not necessarily exactly equate with a historical-critical or grammatical-historical analysis of the text; and they believe that the Spirit can say more than Scripture, although never in contradiction to Scripture (Fogarty, 2015:5-6). A hermeneutic that focuses only on what the original author

31 Davies' (2007:170) remark is noteworthy that Pentecostal preaching must remain inductive rather than deductive, by letting the text tell its story instead of forcing it into a convenient mould.

32 The accusation has been made that Pentecostals never seem to get beyond Luke-Acts (Klaus, 2006:12), an accusation that Pentecostals should consider seriously. Macchia (2006:153) responds by combining Pauline and Lukan pneumatology and writes that "Spirit Baptism as an eschatological partnership in the kingdom of God by faith involves Christian initiation and a release of the Spirit in life for power in witness. The broad theological framework of Spirit Baptism as a divine act in inaugurating the kingdom of God involves theologically for Luke and the Pentecostals an experience of the Spirit in power for witness." 
meant (if it is possible to determine it) do not satisfy Pentecostal sentiments, which assert that the spiritual and extraordinary supernatural experiences of biblical characters are to be duplicated for contemporary believers. A Pentecostal hermeneutic will always take into account the role of the Spirit and the impact of personal experience.

\section{By Way of Conclusion}

The question was asked: Why do Pentecostal people reach different conclusions when they read the Bible compared to believers in other Christian traditions, such as the Catholic and Reformed traditions? And how does their hermeneutics inform Pentecostals' practice? It has been argued that a Pentecostal hermeneutics emphasises three elements: the interrelationship between the Holy Spirit as the One animating Scriptures and empowering the believing community. For them, the experience of an encounter with God through his Spirit is imperative, and interpretation of the information contained in the Bible is determined by their praxis.

\section{BIBLIOGRAPHY}

Althouse, P 2009. "Towards a Pentecostal ecclesiology: Participation in the missional life of the triune God." Paper read at the $38^{\text {th }}$ Annual Meeting of the Society for Pentecostal Studies, 1-19.

Anderson, A 2003. "Towards a Pentecostal Missiology for the Majority World." Paper read at the International Symposium on Pentecostal Missiology, Asia-Pacific Theological Seminary, 1-19.

Archer, KJ 1996. "Pentecostal hermeneutics: Retrospect and prospect." Journal of Pentecostal Theology 4(8):63-81.

Archer, KJ 2009. A Pentecostal Hermeneutic: Spirit, Scripture and Community. Cleveland: CPT.

Arrington, FL 1996.'The Use of the Bible by Pentecostals. PNEUMA: The Journal of the Society for Pentecostal Studies 16(1-2):101-107.

Autry, AC 1993. "Dimensions of hermeneutics in Pentecostal focus." Journal of Pentecostal Theology 1(3):29-50.

Bahnsen, G 1993. “A Reformed confession regarding hermeneutics.” PT173. Covenant Media Foundation. http://www.cmfnow.com/articles/pt173.htm. Accessed 2013-12-30.

Burger, I \& Nel, M 2008. The Fire Falls in Africa: A History of the Apostolic Faith Mission of South Africa. Vereeniging: Christian Art.

Cargal, TB 1993. "Beyond the Fundamentalist-Modernist controversy: Pentecostals and hermeneutics in a postmodern age." PNEUMA: The Journal of the Society for Pentecostal Studies 15:163-187.

Clark, M 2011. "Pentecostal ecclesiology: A view from the Global South.” EPCRA Conference, Riga, Latvia. http://trn.sagepub.com/content/30/1/46.full.pdf. Accessed 2015-01-31.

Clark, M 2013. "Pentecostalism and philosophy of religion." Paper read at the Philosophy and Religious Practices Workshop, University of Wales. 
https://philosophyreligion.wordpress.com/2013/05/19/matthew-clark-pentecostalisand-philosophy-of-religion/. Accessed 2015-01-31.

Clark, MS \& Lederle, HI 1989. What is Distinctive about Pentecostal Theology?

Miscellanea Specialia 1, Unisa. Pretoria: University of South Africa.

Clark, MS 1997. An investigation into the nature of a viable Pentecostal hermeneutic. DTh thesis, University of South Africa.

Cullmann, O 1956. The early church. London: SCM.

Daniels, WH (ed.) 1877. Moody: His words, works, and workers. New York: Nelson and Phillips.

Davies, A 2007. "A new teaching without authority: Preaching the Bible in postmodernity." The Journal of the European Pentecostal Theological Association 27(2):161-172.

Dayton, DW 1987. Theological Roots of Pentecostalism. Peabody, MA: Hendrickson.

De Beer, FJ 2014. The valence of Spirit manifestation, and its influence on the transformation of the mind and redemption of the body and flesh according to Romans 8 and 12 and its application in a secular society. DLitt et Phil thesis, University of Johannesburg.

Du Plessis, DJ 1963. The Spirit bade me go. Revised and enlarged. California: self-published.

Ellington, SA 1996. "Pentecostalism and the authority of Scripture." Journal of Pentecostal Theology 9:16-38.

Erickson, MJ 1983. Christian Theology. Second edition. Grand Rapids: Baker Academic.

Ervin, HM 1985. "Hermeneutics: A Pentecostal option," in Elbert, P (ed.) Essays on Apostolic Themes: Studies in Honour of Howard M. Ervin. Peabody: Hendrickson.

Fackre, G 1996. The Christian story: A narrative of basic Christian doctrine. Third edition. Grand Rapids: Eerdmans.

Fish, S 1980. Is there a text in this class? The authority of interpretive communities. Cambridge: Harvard University Press.

Fogarty, S 2015. “Toward a Pentecostal hermeneutic.” Webjournals.ac.edu.au. http://webjournals.ac.edu.au/journals/PCBC/vol5-no2/toward-a-pentecostalhermeneutic/. Accessed 2015-04-03.

Friesen, A 2009. "The called out of the called out: Charles Parham's doctrine of Spirit Baptism." The Journal of the European Pentecostal Theological Association 29(1):43-56.

Gadamer, HG 1965. Wahrheit und Methode: Grundzüge einer philosophischen Hermeneutik. 2. Auflage. Tübingen: Mohr.

Gadamer, HG 1976. Philosophical hermeneutics. Tr. and ed. by DE Linge. Berkeley: University of California Press.

Gadamer, HG 1979. Truth and method. Tr. by William Glen-Doepel. London: Sheed and Ward.

Gee, D 1932. Pentecost. Springfield: Gospel Publishing House.

Gräbe, PJ 1990. $\Delta v v \alpha \mu 1 \sigma$ in the sense of power in the main Pauline Letters. Unpublished DD dissertation, University of Pretoria.

Gräbe, PJ 1997. "Hermeneutical reflections on the interpretation of the New Testament with special reference to the Holy Spirit and faith," in Gräbe, PJ \& Hattingh, WJ (eds.) The Reality of the Holy Spirit in the Church: In Honour of F.P. Möller, 14-26. Pretoria: JL van Schaik. 
Grudem, W 1994. Systematic theology: An introduction to Biblical doctrine.

Nottingham: IVP.

Harper, M 2008. "The waves keep coming in." The Journal of the European Pentecostal Theological Association 28(2):102-117.

Harrington, HK \& Patten, R 1994. "Pentecostal Hermeneutics and Postmodern Literary

Theory." PNEUMA: The Journal of the Society for Pentecostal Studies

16(1-2):109-114.

Hart, T 1995. Faith thinking: The dynamics of Christian theology. London: SPCK.

Hawk, LD 1991. Every promise fulfilled: Contesting plots in Joshua. Louisville:

Westminster/John Knox.

Hollenweger, WJ 1988. The Pentecostals. London: SCM.

Horn, JN 1989. From rags to riches: An analysis of the Faith movement and its relation to the classical Pentecostal movement. Pretoria: University of South Africa.

Horton, M 2011. The Christian faith: A Systematic Theology for pilgrims on the way. Grand Rapids: Zondervan.

Huckle, JS 2009. "The contemporary use of the gift of prophecy in gatherings of Christians in comparison with their use in the $20^{\text {th }}$ century." The Journal of the European Pentecostal Theological Association 29(1):73-86

Jeanrond, WG 1982. "Biblical interpretation as appropriation of texts: The need for a closer cooperation between biblical exegetes and systematic theologians." Proceedings of the Irish Biblical Association 6:1-18.

Jeanrond, WG 1986. Text Und Interpretation als Kategorien Theologischen Denkens. Hermeneutische Untersuchungen zur Theologie 23. Tübingen: JCB Mohr.

Johns, CB 1993. Pentecostal formation: A pedagogy among the suppressed. JPTSup, 2. Sheffield: Sheffield Academic Press.

Jooste, LJ s.a. Lewenskets van Dr FP Möller. Gepubliseerde MTh-verhandeling, Universiteit van Suid-Afrika. Westdene: AGS Drukkers.

Kaiser, WC \& Silva, M 1994. Introduction to Biblical hermeneutics: The search for meaning. Revised, expanded edition. Grand Rapids: Zondervan.

Kasper, W 1989. "Prolegomena zur Erneuerung der Geistlichen Schriftauslegung," in Frankemöller, H \& Kertelge, K (Hg.) Vom Urchristentum zu Jesus: Für Joachim Gnilka, 508-552. Freiburg: Herder.

Kennedy, P 2006. A modern introduction to theology: New questions for old beliefs. London, New York: IB Tauris.

Klaus, BD 2006. "Pentecostalism and mission." Paper read at the American Society of Missiology, 1-18.

Lake, JG 1994. John G Lake: His life, his sermons, his boldness of faith. Fort Worth: Kenneth Copeland Publications.

Lategan, B 2009. "New Testament hermeneutics (Part I): Defining moments in the development of Biblical hermeneutics," in Du Toit, A (ed.) Focusing on the message: New Testament hermeneutics, exegesis and methods, 13-63. Pretoria: Protea.

Lategan, B 2009. "New Testament hermeneutics (Part II): Mapping the Biblical hermeneutics," in Du Toit, A (ed.) Focusing on the message: New Testament hermeneutics, exegesis and methods, 65-105. Pretoria: Protea.

Lategan, BC 1992. "Hermeneutics," in Freedman, DN (ed.) Anchor Bible Dictionary 3:153-154. New York: Doubleday. 
Letson, H 2007. "Pentecostalism as a paradigm shift: A response to Hans Kung's paradigmatic model." The Journal of the European Pentecostal Theological Association 27(2):104-117.

Liardon, R 1996. God's generals: Why they succeeded and why some failed. New Kensington: Whitaker.

Lochmann, JM 1982. Das Glaubensbekenntnis: Grundriss der Dogmatik im Anschluss an das Credo. Gütersloh: Gütersloher Verlagshaus Gerd Mohn.

Luther, M 2004 (1566). Table Talk. Tr. by W Hazlitt. Philadelphia: Lutheran Publication Society.

Ma, W 2005. "Full circle mission: A possibility of Pentecostal Missiology." Asian Journal of Pentecostal Studies 8(1):5-27.

Maas, A 1910. "Hermeneutics," in The Catholic Encyclopedia. New York: Robert Appleton Company. New Advent: http://www.newadvent.org/cathen/07271a.htm. Accessed 2013-12-30.

Macchia, F 2006. Baptized in the Spirit: A global Pentecostal theology. Grand Rapids: Zondervan.

Mahan, A 1870. The baptism of the Holy Spirit. New York: Palmer and Hughes.

McClung, LG (ed.) 1986. Azusa Street and beyond: Pentecostal missions and church growth in the twentieth century. South Plainfield: Bridge.

McLean, MD 1994. "Toward a Pentecostal hermeneutic.” Journal of Pentecostal Studies 5:35-49.

McQueen, LR 2009. Joel and the Spirit: The cry of a prophetic hermeneutic. Cleveland: CPT.

Menzies, R 1991. The development of early Christian pneumatology with special reference to Luke-Acts. JSNTSup 54. Sheffield: JSOT.

Menzies, RP 1970. Essence of Pentecostalism. Unpublished document serving as part of the Dialogue between the Roman Catholic Church and the Pentecostal movement, 3 September 1970.

http://enrichmentjournal.ag.org/top/holyspirit_articledisplay.cfm?targetBay=1b574d ef-b227-4617-bfc7-

a02cdb926902\&ModID=2\&Process=DisplayArticle\&RSS_RSSContentID=15156\& RSS_OriginatingChannelID=1170\&RSS_OriginatingRSSFeedID=4486\&RSS_Sour ce $=$. Accessed 2014-05-07.

Menzies, RP 1994. "Jumping Off the Postmodern Bandwagon.” PNEUMA: The Journal of the Society for Pentecostal Studies 16(1-2):115-120.

Mittelstadt, MW 2004. The Spirit and suffering in Luke-Acts: Implications for a Pentecostal theology. London, New York: T\&T Clark.

Mittelstadt, MW 2010. Reading Luke-Acts in the Pentecostal tradition. Cleveland: CPT.

Möller, FP 1975. Die diskussie van die charismata soos wat dit in die Pinksterbeweging geleer en beoefen word. Braamfontein: Evangelie Uitgewers.

Möller, FP 1991. Woord van lig en lewe: Deel 1: 'n Pinkster Dogmatiese Studie. Westdene: AGS Drukkers.

Möller, FP 1997. "Christ and Pentecostalism," in Gräbe, PJ \& Hattingh, WJ (eds.) The reality of the Holy Spirit in the church: In honour of FP Möller, 140-144. Pretoria: Van Schaik.

Moore, RD 1995. "Deuteronomy and the Fire of God: A critical charismatic interpretation." Journal of Pentecostal Theology 3(7):11-33. 
Nelson, PC \& Wawire, P 2004. Bible doctrines. Africa's Hope Discovery Series. Springfield: Gospel Publishing House.

Olson, RE 1999. The story of Christian theology: Twenty centuries of tradition \& reform. Leicester: Apollos.

Onyinah, O 2012. "Pneumatological foundations for mission: From a Pentecostal perspective." International Review of Missions Nov 2012:1-3.

Palmer, R 1969. Hermeneutics: Interpretation theory in Scheleiermacher, Dilthey, Heidegger, and Gadamer. Evanston: Northwestern University Press.

Pelikan, J 1971. The Emergence of the Catholic tradition (100-600): The Christian tradition. A history of the development of doctrine. Chicago \& London: University of Chicago Press.

Penney, JM 1997. The missionary emphasis of Lukan pneumatology. Sheffield: Sheffield Academic.

Pinnock, CH 1993. "The work of the Holy Spirit in Hermeneutics." Journal of Pentecostal Theology 1(2):3-23.

Poloma, MM 1989. The Assemblies of God at the crossroads: Charisma and institutional dilemmas. Knoxville: University of Tennessee Press.

Rance, D 2009. "Fulfilling the apostolic mandate in apostolic power: Seeking a Spiritdriven missiology and praxis." Paper presented at the $38^{\text {th }}$ Annual Meeting of the Society for Pentecostal Studies, 1-25.

Reese, R 2007. "The surprising relevance of the Three-Self formula." Mission Frontiers July-August 2007:25-27.

Ricoeur, P 1975. "Philosophical hermeneutics and theological hermeneutics." Studies in Religion/Sciences Religieuses 5:14-33.

Schafroth, V 2009. "An exegetical exploration of 'Spirit' references in Ezekiel 36 and 37." Journal of the European Theological Association 29(2):61-77.

Schnackenburg, R 1974. Belief in the New Testament. Tr. by J Moiser. New York: Paulist.

Schütz, C 1985. Einführung in die Pneumatologie. Darmstadt: Wissenschaftliche Buchgesellschaft.

Sheppard, GT 1994. "Biblical interpretation after Gadamer." PNEUMA: The Journal of the Society for Pentecostal Studies 16(1-2):121-141.

Stronstad, R 1984. The charismatic theology of St. Luke. Peabody: Hendrickson.

Stronstad, R 1992. "Pentecostal experience and hermeneutics." Paraclete 26(1):18,25

Stuhlmacher, P 1979. Vom Verstehen des Neuen Testaments: Eine Hermeneutik. Grundrisse zum Neuen Testament, NTD Ergänzungsreihe 6. Göttingen: Vandenhoeck \& Ruprecht.

Thiselton, AC 1992. New horizons in hermeneutics. Grand Rapids: Zondervan.

Thomas, JC 1994. "Women, Pentecostals and the Bible: An experiment in Pentecostal hermeneutics." Journal of Pentecostal Studies 5:41-56.

Torrey, RA 1895. The baptism with the Holy Spirit. New York: Fleming H Revell.

Turnage, M 2003. "The early church and the axis of history and Pentecostalism: Facing the $21^{\text {st }}$ century: Some reflections." Journal of the European Pentecostal Theological Association 23:4-29.

Van der Walt, SJ \& Jordaan, GJC 2004. "Die kontekstualisering van die Nuwe Testament binne ' $\mathrm{n}$ postmodernistiese paradigma: Die skep van betekenis of die toepas van betekenis." In die Skriflig 38(4) 2004:495-517 
Veenhof, J 1987. “The Holy Spirit and hermeneutics." Scottish Bulletin of Evangelical Theology 5:105-122.

Wendland, HD 1952. "Das Wirken des Heiligen Geistes in den Gläubigen nach Paulus." Theologische Literaturzeitung 77:457-470.

Wessels, WJ 1992. "Skrifgebruik en samelewing: Die Apostoliese Geloof Sending van Suid-Afrika." In die Skriflig 26(3):369-384.

Williams, JR 2015. "The Pentecostal reality." http://www.cbn.com/spirituallife/biblestudyandtheology/drwilliams/bk-pentacostalch03.aspx. Accessed 2015-01-31.

Wilson, E 1998. Strategy of the Spirit: J Philip Hogan and the growth of the Assemblies of God worldwide 1959-1990. Oxford: Regnum. 